\title{
Interracial Trust between Black Doctoral Student Protégés and White Mentors
}

\author{
Eric M. Brown \\ DePaul University
}

U. S. A

Tim Grothaus

Old Dominion University

U. S. A.

\begin{abstract}
Psychologists have found that many Black persons in the United States have significant levels of mistrust of White persons. This serves as a protective factor in response to pervasive structural and systemic racism. Yet interracial trusting relationships exist. In this phenomenological study, 10 Black counseling doctoral students described their interracial trust experiences with White faculty and/or clinical supervisor mentors. The authors constructed six themes from the data: setting less rigid boundaries, practicing transparency, taking the initiative, being congruent, honoring the proteges' strengths and experiences, and advocating for equity. Implications and strategies for supervisors and educators are shared.
\end{abstract}

KEYWORDS: Trust, mentoring, multicultural, supervision, interracial

\author{
Trust and Mentoring \\ Methodology \\ Results \\ References \\ Author Contact
}

\begin{abstract}
Despite the claim in American higher education to be at the forefront of critical thinking in regards to racism and oppression, faculty and students of color continue to report racial inequities that affect their academic development. The relationship between faculty and students in graduate education can serve as a pivotal catalyst for the students excelling within a given profession. Therefore, the mistrust that minoritized students have of White professors, substantiated by numerous experiences of interpersonal and systemic racism, may hinder growth-fostering relationships with White allies. This may be especially true for Black graduate students, as Black persons have historically had high mistrust of White persons in the U.S. (Terrell \& Terrell, 1981). Therefore, interracial mistrust, which serves as a protective factor for Black persons, decreases the chances of the type of interracial academic relationships that would propel Black professionals forward into their careers. We currently lack research that examines positive Black-White,
\end{abstract}


student-faculty relationships within graduate education and how such dyads enable mentoring relationships.

Mentoring of doctoral students, optimally a beneficial and trusting relationship focused on supporting protégé development, is critical for student success (Baker \& Moore, 2015; Chan et al., 2015; McCoy et al., 2015; Protivnak \& Foss, 2009; Rademaker et al., 2016). Indeed, positive mentoring with protégés of color has been linked with enhanced academic and career success, degree completion, professional growth, social and cultural capital, professional identity, critical thinking skills, and self-efficacy (Chadiha et al., 2014, Chan et al., 2015; Gaddis, 2012). Benefits often accrue for mentors also, such as increased job satisfaction, job performance, professional reputation, personal and professional development, and career success (Boswell et al., 2015; Chadiha et al., 2014; Chan et al., 2015; Luedke, 2017).

However, mentoring can also be an implement of oppression, depending upon factors such as the mentor's cultural competence and the level of trust the protégé imbues in the relationship (Luedke, 2017; McCoy et al., 2015). For example, Black graduate students have often found that White faculty exhibit insufficient cultural responsiveness and/or do not proactively proffer positive support (Baker \& Moore, 2015; Haskins, et al., 2013; Henfield et al., 2013). Understandably, protégés of color tend to prefer mentors who share their racial identity (Brooks \& Steen, 2010; Brown \& Grothaus, 2019). Yet, given the underrepresentation of Black faculty in graduate education programs and the established advantages of positive mentoring, Black doctoral students could benefit from co-constructing trusting relationships with White mentors (Brooks \& Steen 2010; Cartwright et al., 2018; Chan et al., 2015; Haizlip, 2012).

\section{Trust and Mentoring}

In the academy, Black students and faculty continue to experience racism, which engenders mistrust of White faculty and supervisors (Baker \& Moore, 2015; Brooks \& Steen, 2010; Haskins et al., 2013; Henfield et al., 2013; Holcomb-McCoy \& AddisonBradley, 2005). While cultural mistrust can be a healthy adaptive factor protecting Black persons from harm due to White racism, higher levels of cultural mistrust can be detrimental to Black persons' psychological health (Bell \& Tracey, 2006; Townes et al., 2009). In addition, with trust being a key component of successful academic mentoring relationships, mistrust can be a substantive impediment to forming these beneficial interracial affiliations (Chan et al., 2015; Johnson-Bailey \& Cervero, 2004; McCoy et al., 2015).

Given the disproportionally large trust gap in Black-White relationships and the disproportionately low representation of Black educators (and high numbers of White faculty), Black doctoral students seeking mentoring will likely need to access positive, trusting relationships with White faculty and supervisors (Cartwright et al., 2018; Smith, 2010). Yet, empirical inquiries concerning the construction of these beneficial relationships is in short supply.

With regard to building effective mentoring relationships, trust is widely endorsed as an essential ingredient (Boswell et al., 2015; Eller et al., 2014; Leck \& Orser, 2013; McCoy et al., 2015; Rademaker et al., 2016). Trust in a mentor involves the relative vulnerability of the protégé along with positive expectation or reliance on the mentor 
(Chun et al., 2010; Keller et al., 2015). Yet, White faculty often struggle with mentoring students of color and Black students often harbor explicable cultural mistrust towards Whites due to experiences of racism in society and in their graduate programs (Baker \& Moore, 2015; Brooks \& Steen, 2010; Henfield et al., 2013; Holcomb-McCoy \& AddisonBradley, 2005; Johnson-Bailey \& Cervero, 2004; McCoy et al., 2015). Indeed, among demographic categories, ethnoracial difference has the biggest overall impact on trust. In addition, Blacks and Whites have the largest inter-ethnic or racial trust gap - even accounting for class differences (Smith, 2010).

Black students may be justifiably wary about trusting White faculty, which makes the establishment of an effective mentoring relationship more difficult. Brown and Grothaus (2019) discovered that Black doctoral students in trusting relationships with White mentors experienced benefits from these relationships which may have served as a protective factor for the racism experienced in their programs and clinical sites. Other explorations of Black graduate education students' experiences have illuminated their struggles and resilience amidst myriad challenges, such as racism and the systemic inequity common in institutions that are predominately White (Baker \& Moore, 2015; Haskins et al., 2013; Henfield et al., 2013; Luedke, 2017; McCoy et al., 2015). Yet, despite the clear positive potential of these relationships, the literature examining successful interracial mentoring relationships is limited, especially from the perspectives of protégés (Brown \& Grothaus, 2019; McCoy et al., 2015). In addition, relatively little attention is given to factors which may assist in building these beneficial and constructive interracial mentoring relationships (Chan et al., 2015). This phenomenological inquiry sought to address this gap in the professional literature by investigating factors that contributed to successful and trusting interracial mentoring relationships. This study's purpose was to understand and represent Black counselor education doctoral students' lived experiences and thoughts regarding the characteristics of White mentors who earned their trust.

\section{Methodology}

Phenomenological inquiry focuses on the lived experiences of persons, amplifying their voices as it seeks to ascertain and describe the meanings given to the phenomena in question (Hays \& Singh, 2012; Moustakas, 1994). This research tradition gives priority to how persons consciously experience and think about their reality (Wertz, 2005). Gathering and analyzing the thick and descriptive data shared by participants allows researchers to illuminate the essence of the participants' experiences of the phenomenon (Creswell, 2013). Our study was guided by the following research question: What are the lived experiences of Black doctoral students who have previously participated or are currently in trusting relationships with White mentors within the counseling profession?

\section{Participants}

Creswell (2013) suggests a range of three to ten participants for phenomenological research. For this study, ten participants were interviewed. Participants were found through a social network of Black doctoral students and faculty members and then also using snowball sampling. The selection criterion for inclusion was being a Black doctoral student in a counselor education program who had trusted a White faculty member or supervisor within the profession as a mentor. The students who expressed interest in 
participating, met this criterion, and gave informed consent were selected as the participants.

The doctoral students interviewed were enrolled in predominately White institutions (PWIs) located in the Mid-Atlantic $(n=5)$, Southeast $(n=3)$, Midwest $(n=1)$, and Southwest $(n=1)$ U.S. Their institutions were classified as featuring moderate $(n=1)$, higher $(n=6)$, and highest $(n=3)$ levels of research activity (Carnegie Classification of Institutions of Higher Education, 2015).

There were six female and four male participants with an age range from the mid 20 's to the early 50's, including seven participants in their 20's. Seven of the ten participants were first generation college students (i.e., neither parent having graduated from a college or university) while three were continuing generation students (i.e., having at least one parent graduate from the aforementioned). Half identified both White clinical supervisors and counselor educators as trusted mentors. Three identified just White faculty and two identified just White clinical supervisor(s) as their trusted mentor. The ten participants identified a total of 22 trusted White mentors collectively. During the interview process, the doctoral students chose the pseudonyms used here.

\section{Data Collection}

After securing exempted approval from the first author's university internal review board, an introductory letter and a demographic questionnaire were emailed to potential participants. To provide time for reflection on the topic, all participants who gave written consent to be interviewed received the protocol questions 48 hours prior to the meeting (James, 2014). The first author then conducted interviews either face to face or via a secure connection on Adobe ${ }^{\circledR}$ Connect ${ }^{\mathrm{TM}}$. Initial interviews lasted between 30 and 60 minutes.

The researchers used semi-structured interviews with questions focused on the participants' experiences of interracial trust in mentoring relationships (Creswell, 2013; Hays \& Singh, 2012). The first author initially constructed the interview protocol based upon a review of salient professional literature. The research team members and three counselor educator consultants then reviewed the questions for face validity and created the final version. Inquiries included: (a) What did you experience within this/these interracial relationship(s) that enabled you to trust the White mentor(s)? (b) Can you share the differences between the Whites you chose to trust and those you trusted less? (c) Based on your experience, how would you define trust in an interracial relationship? (d) How did your experience of interracial trust differ, if at all, from your experience of trusting Blacks? (e) How would you define a mentoring relationship?

A professional transcriptionist confidentially transcribed the interviews. Participants received their transcript within two days of the interview for member checking (Creswell, 2013). A follow up interview, scheduled within a week of transcript delivery, was conducted to allow participants to clarify and/or expound on anything shared in the initial inquiry. Eight of the ten participants participated in the follow up interviews, which ranged from 10 to 20 minutes in length. The transcripts for both interviews were then shared with the research team for data analysis. 


\section{Research Team}

To mitigate researcher bias and enhance the trustworthiness of the results, the first author constructed a data analysis team with two counselor education doctoral students. In addition, he retained an external auditor and also engaged in regular consultation with a counselor educator that he considered a mentor (Hays et al., 2016). All research team members had completed at least one doctoral level qualitative research class and had been involved in previous qualitative inquiries. All five also actively discussed their assumptions about the experiences of Black doctoral students who trusted White mentors throughout the process (Creswell, 2013; Wertz, 2005).

The lead researcher is a Black male and was a doctoral student at the time of the inquiry. As a result of his race and doctoral student status, he is an "insider," sharing these identities and aspects of positionality with the participants. He experienced both racism and the presence of multiple positive relationships with White mentors, including the second author, during his journey in higher education. His assumptions, which were shaped by his social and political experiences, included being inclined to believe that the doctoral student participants might have had positive past experiences with White individuals in positions of power in educational settings. Along with the external auditor and the counselor educator consultant (both White, male, counselor educators with identified interest in cultural competence and also multiple published qualitative studies), he also believed the mentors' comfort level in discussing race, racism, and their own White privilege would likely influence the doctoral students' level of trust. Finally, the same trio thought that the participants might also believe that their mentors were invested in their academic and professional development.

For data analysis, the lead author was joined by two White doctoral students, a male and a female, both in their early 30's. Each had participated in multiple multicultural counseling classes. The assumptions they acknowledged in their attempt to balance subjectivity and reflexivity included the belief that a long-term relationship, similar professional interests, and mentors' demonstrations of empathy toward the students could be central to building interracial trust. All researchers discussed these expectations and potential biases before data collection. We also invited challenges and discussion about the potential influence of our assumptions throughout the research process in order to more clearly hear and represent the participants' voices.

\section{Data Analysis}

Moustakas' (1994) process of data analysis was used for all of the interview transcripts, first individually then collectively, until consensus was achieved. Researchers engaged in horizonalization, identifying codes that were similar and considering each code as holding equal importance. Redundant codes were then eliminated. Each research team member categorized non-repeating meaning units related to the unique experiences of each participant. This was followed by each team member creating clusters and themes from the data for each individual interviewed, then across the participants.

The three data analysis team members met after analyzing transcripts from the first two doctoral protégés and again after the tenth participant to engage in consensus coding. The development of the final consensus codebook occurred once the team 
concluded that the data were saturated after analyzing ten first and eight second interview transcripts. Textural-structural descriptions from the transcripts were used to illustrate codes and themes created from the data (Hays \& Singh, 2012).

In addition to continued discussions about the potential influence of biases throughout the process, the primary researcher was the last to share his codes and themes during the team meetings, hoping to not unduly influence the consensus coding due to his status as the only Black researcher. The three researchers analyzing the data had separately developed similar codes and themes from the data and consensus was achieved relatively quickly.

The research team employed multiple methods to ensure trustworthiness, which refers to the validity of the study, especially the accurate reflection of the participants' voices and perspectives (Hays et al., 2016; Hunt, 2011). The efforts to enhance trustworthiness included the team's fidelity to Moustaka's analysis process and sensitivity to team member biases. Other measures employed included ongoing discussions regarding assumptions and biases, the triangulation of multiple researchers, keeping reflective journals, using consensus coding, member checking with participants, interviewing most of the participants twice, using an audit trail that was reviewed and approved by an external auditor, and utilizing thick descriptions of the participants' experiences and featuring their voices (Hays \& Singh, 2012). In addition, negative case analysis was used in an attempt to disconfirm codes and themes created by the research team. Data that contradicted identified themes are also included in the results (Creswell, 2013).

\section{Limitations}

Researcher bias had the potential to influence the study. To ameliorate this, the research team discussed biases throughout the process, kept reflective journals, used consensus coding, and had an external auditor. In addition, participants' answers to questions may have been influenced by social desirability. Also, while the inquiries' focus on race yielded rich data, the exclusive emphasis on this one aspect of identity likely discouraged discussion related to the intersectionality of participants' cultural identities. Finally, with the absence of consensus definitions for mentoring or trust, the researchers chose not to define these terms a priori for participants. Instead, participants were invited to construct their own meanings. While this honored the participants' experiences and voices, the varying connotations likely influenced the results and may impact the readers' ability to clearly conceptualize the constructs.

\section{Results}

The researchers constructed six themes from the data regarding strategies for mentors building trusting interracial mentoring relationships: setting less rigid boundaries, practicing transparency, taking the initiative, being congruent, honoring the protégé's strengths and experiences, and advocating for equity. All of the participants indicated that their mentor's openness and genuineness allowed them to be vulnerable, which is a prerequisite for a trusting relationship. 


\section{Setting Less Rigid Boundaries}

Seven participants spoke about their White mentor getting to know them holistically and not confining the relationship to just professional or academic topics. Simone shared, "We would talk about everything really. She wasn't only like a mentor for the profession. She was almost a mentor for life." Kelly said,

Sometimes professors set these boundaries as, "I'm the professor, you are the... doc student" or whatever... they set boundaries in what is acceptable to talk about, what are acceptable manners of acting with you, and I find that to be really limiting...it's probably a cultural thing, but when those boundaries are rigid... I have a harder time working within those parameters because...I don't know what I can talk to you about or can come to you with. If I'm struggling personally, is it okay if I come in crying in your office because if those boundaries are really rigid, I don't feel like I can do that.

These participants appreciated their mentors having less "rigid boundaries," which allowed the protégés to be vulnerable and trusting in order to share about their experiences as Black students.

These participants also signaled the importance of the White person they chose to trust creating a space for them to discuss oppressive and challenging experiences. For example, Kelly noted,

We don't have to provide space every single time...the police shoot a Black man or every single time something happens, but I think that... providing that space for your mentees to talk about it is really important. I think if there's not, if that space isn't provided or if there seems to be this unawareness of historical but also current social and political context that are contributing to our experiences as Black people, I just don't think that I would trust them as much

For these students, the White mentor provided a safe space to express emotions, ask questions, and discuss challenges and inequities.

\section{Practicing Transparency}

Six participants appreciated their mentors' efforts to be transparent, the second theme the researchers created from the data. This helped to facilitate trust. Simone captured this sentiment when she stated, "I didn't really realize that the transparency of another person is what was able to make me switch to trusting White people." For Simone, her mentor's disclosure was the antithesis of her previous experiences with White deception. In addition, Nicole stated:

For him to be transparent with that made me open up more, and willing to be transparent about what I'm going through, my thoughts, my feelings with the program and outside of the program. I think he kind of modeled that for me.

Nicole would later go on to say that she believed that interracial trust in mentoring relationships needed to go both ways. That for her to trust a White mentor she would need to believe that they trusted her; therefore, her mentor modeling transparency was significant for their relationship. 
Two of these participants indicated that their White mentors chose to disclose personal experiences of marginalization. For example, Garvey noted that his mentor shared a hidden marginalized identity that they had in common which helped foster his trust in her. This type of transparency entailed vulnerability, which is central to trust. The mentors entrusting their proteges with such personal information engendered greater motivation for the student to trust their White mentor.

\section{Taking the Initiative}

The third theme the researchers found in the data was taking initiative. Six participants indicated that their mentor's willingness to broach topics such as racism and the marginalization of persons of color helped build trust. For example, Nicole said,

What I've been saying is that they are real individuals and not afraid to have those real discussions, not afraid to have discussions about identity, and my identity, me being Black, and...them being White, and then owning who they are, not being shamed or anything like that. That goes a long way for me.

Kelly felt strongly that mentors choosing to initiate challenging conversations was crucial, instead of "placing the burden on your mentee to bring it up."

Beyond just broaching cultural topics in an already established relationship, two students reported that they appreciated when their White mentors initiated making connections with Blacks. Kelly said,

People are proclaiming themselves to be allies by wearing a safety pin and that shows that they're a safe person and if somebody feels threatened, if there's a marginalized group that feels threatened, then that safety pin shows that they can seek out a safe person... That's a really nice gesture, but, at the same time, once again, the burden is falling on the marginalized person to seek out a person of power. It's really nice that you're wearing the safety pin, but why don't you seek out the marginalized person.

Nicole shared that the relationships should not be one way, "I feel like I shouldn't always have to seek you out, I feel like you should seek me out at some point as well." These women believed that White initiative in relationship building may help facilitate interracial trust.

In contrast to White persons who took initiative, two students spoke of mistrusting Whites who avoid the topic of race. For example, Kelly shared, "I would say, in regards to people who I have chosen to trust less, there's been less of a willingness... we never have conversations about race or cultural differences." However, Jessica sounded a cautionary note, indicating that she did not want a White faculty member or supervisor to bring up uncomfortable topics unless the mentor also appreciated the power differential between them.

\section{Being Congruent}

Congruence was the fourth theme created from the data, which summarized how more than half of participants spoke of observing White faculty in their discernment of who to trust. For five participants, witnessing the mentor's actions aligning with their professed values enhanced their interracial trust. For example, Kelly said, 
They're not just saying that they're a safe person but their actions back that up... Don't just say you're an ally and that we're multicultural, like, show me... They had some kind of social justice orientation that was reflected in their research... Whether or not it's pertaining to race, even if it's LGBT (or) undocumented immigrants, whatever it is...

Garvey noted that he would check out the offices of potential White mentors to see if they had any interest in issues of racial justice: "I need visible support...you can have a poster or a quote... show me something that I can see that you connect or are willing to connect with Black people." These participants inferred that a White person's sensitivity and advocacy for any oppressed group may be a sign that she or he is trustworthy.

These students observed Whites to see how they handled certain situations, looking for evidence of their cultural competence. Simone shared, "If I can observe a White person that gets along with other Blacks or other people from different cultures and they seem to...be genuine, then...I would feel like, oh, okay, maybe they've already passed the test." Some of these Black doctoral students also noted that the interracial trust grew when they could disagree with their mentors without negative repercussions. Harpo wanted Whites to understand "that having a different opinion doesn't mean I'm against you, doesn't mean I don't like you."

Furthermore, these students also observed faculty relations as signs of who they could trust. Two protégés stated that the internal strife and mistrust among counselor education faculty members were impediments to trust. Nicole noted, "I've seen how the politics work and how they interact with each other, White faculty with other faculty members.... Makes me even more apprehensive because of all of their...drama." In addition, Darnell indicated that if he witnessed that Whites did not trust each other, he would choose not to trust them.

\section{Honoring the Protégé's Strengths and Experiences}

Honoring the experience of the protégé was the fifth theme created from the data. Mentors who expressed a deep appreciation of the Black struggle and validated the participant's experience paved the way for increased trust. Three participants noted that interracial mentoring can benefit both the Black mentee and the White mentor. They believed that Whites who honored their experience could grow in their own multicultural competency as a result of the relationship. Chad stated that,

Just being able to...share those experiences and even talking about what it's like for me to walk into a room professionally with a bunch of other White counselors and being the only Black male counselor in the room. Those conversations, I think, help build me as a mentee, but also help build my mentor.

These students saw themselves as resources for their mentors through sharing their lives, experiences, and insights as Black students in a White space.

Three participants also indicated that their mentors displayed confidence in them when they encouraged or challenged them to do better academic work. Nicole shared, "he challenges me. He is not afraid to call me out on my B.S." Anthony shared this story,

...[he] kind of pulled me to the side one day after class and was like, "Hey, you got some potential but I noticed that you're not as engaged as you need to be within 
the class." It was like, "You're doing your work, but are you really putting forth your full potential?" Which is good. Sometimes you need someone to pull you by your coat tail.

These participants stated that they received their mentor's challenge as an honor, signifying that the mentor believed they had greater potential than the participants themselves believed they had.

\section{Advocating for Equity: Use Your Privilege}

The research team identified a sixth theme to capture the participants' belief that their trust increased when White mentors used their privilege and influence to advocate for and with marginalized persons. Half of the participants said it was important for mentors to use their White privilege to benefit students of color. For example, Chad indicated that mentors needed to courageously use their voice and power on behalf of ethnic minorities, even if it cost them some esteem amongst their privileged colleagues. Darnell endorsed "sharing your privileges... whether that be connections with people that you know... writing a letter of recommendation, sharing the knowledge that you have gained."

\section{Discussion}

This study appears to be unique by virtue of both accessing the perspectives of Black doctoral student protégés and also focusing on successful Black-White mentoring experiences and the factors that build these trusting relationships. Unlike the current inquiry, some studies (e.g., Boswell et al., 2015; Eller et al., 2014) acknowledged a deficiency with regard to the diversity of their sample while others focused on gender (e.g., Leck \& Orser, 2013) or junior faculty as protégés (e.g., Cartwright et al., 2018; Chadiha et al., 2014). Inquiries that did investigate the mentoring of ethnic minority students either did not fully address interracial dyads or instead focused on exposing the problems associated with these pairings (e.g., Chan et al., 2015; McCoy et al. 2015).

For example, protégés in our study valued their mentors' awareness and active acknowledgement of the power differential in the relationship. Yet protégés also wanted the mentoring relationship to extend beyond an overly restrictive interpretation of the guideline in the American Counseling Association (ACA) ethical standards to "avoid nonacademic relationships" (ACA, 2014, p. 15), as illustrated by some mentors' exclusive focus on professional or academic concerns. Specifically, this included the protégés' desire for the mentors to help create or provide a safe space to have discussions about professional and personal experiences of oppression, which echoed the findings of previous empirical examinations (Chadiha et al., 2014; Chan et al., 2015). This calls into question not only our individual practices but also the biases in our interpretation of our professional ethical standards.

Yet despite the support for holistic mentoring relationships and safe spaces, this is not necessarily the norm. In both Baker's and Moore's (2015) and Luedke's (2017) inquiries, while some students benefitted from a less rigorously boundaried relationship with their mentor, others found the affiliation to be more rigid and limited to academic concerns. Interestingly, in Luedke's study of staff and administrator mentoring of students

of color, the White mentors tended to engage in more restrictive relationships while the 
administrators and staff of color allowed or cultivated a more inclusive relationship, which attended to both professional matters and personal concerns impacting students' lives. These findings call us to examine our department climates and expectations for their inclusiveness and responsiveness to the needs of all of our students.

Our protégés also expressed a preference for their mentors to be transparent, honest, and to keep it real. As was evident in this study, one possible manifestation of this occurred when mentors respectfully challenged their protégés to broaden their vision for their future or to invest more effort in their current work (Chan et al., 2015; Eller et al., 2014). The aforementioned results are in contrast to recent inquiries where students and faculty of color expressed a need to code switch or assimilate to White culture in order to succeed (Baker \& Moore, 2015; Protivnak \& Foss, 2009). The findings here can also be contrasted with the findings of McCoy et al. (2015), which noted the incongruent attitudes and actions of White faculty (e.g., professing to treat all students as equals but making statements implying that students of color were inferior in terms of academic ability).

In addition, protégés wanted White faculty mentors to be proactive in reaching out to offer support and make connections with students of color, including initiating conversations regarding race, marginalization, and power differential (Chan et al., 2015; Haskins et al. 2013). The reverse was also true: the protégés asserted that faculty avoidance of these candid conversations was an impediment to building a trusting mentoring relationship (Baker \& Moore, 2015; McCoy et al., 2015). Notably, students of color have reported seeing White students receive this proactive support from White faculty while they did not (Baker \& Moore, 2015; Haskins, et al, 2013). Rudolph et al. (2015) referred to this expenditure of extra initiative and effort by students of color in mentoring relationships as a "mentoring tax" (p. 194).

Participants in this inquiry also wanted their mentors to exhibit a congruence with regard to their actions and professed beliefs. To determine the congruence of a potential mentor, protégés in this study might see if mentors "passed the tests" by receiving an endorsement from other persons of color. They might also observe mentor behaviors to witness if the mentors engaged in advocacy and used their White privilege for the benefit of marginalized persons, despite negative repurcussions for the mentor (Cartwright et al., 2018; Chan et al., 2015; Ratts, et al., 2016; Spanierman \& Smith, 2010). This call to clearly enact the values we supposedly embrace is a bracing reminder to examine our practices.

Finally, participants in this study did not expect the White mentors they trusted to be particularly knowledgeable about Black culture or the Black experience. However, the students did articulate a desire for mentors to avoid microaggressions (and acknowledge when they occurred) and to demonstrate humility, interest, and also respect for protégés' experiences, strengths, and cultural capital while appreciating the mutually beneficial nature of the relationship (Butler et al., 2013; Chadiha et al., 2014). Again, as noted by students of color in extant examinations, these wishes often went unfulfilled (Baker \& Moore, 2015; Chan et al, 2015). 


\section{Implications for Educators and Supervisors}

In this study, while the protégés offer specific suggestions to White mentors for building trust, the findings as a whole appear to affirm the need for mentors in the counseling field, and likely the academy in general, to continually cultivate multicultural and social justice competence, especially in the domains of attitudes and beliefs, skills, and actions (Ratts et al., 2016). White educators and supervisors need to actively work to ameliorate their own racial biases along with the deleterious effects these predispositions have on already marginalized students (Malott et al., 2015). Enhancement of cultural humility, an allocentric attitude indicated by respect, openness, genuineness, and curiosity, is also supported both by our data and the extant literature (Davis et al., 2016; Owens et al., 2016).

In addition, instead of solely striving to assist mentees to cope in the existing oppressive climate, for example with expectations that protégés engage in assimilating and damaging "code switching" behavior and language (Baker-Bell, 2020), the protégés called for White mentors to focus on the equitable transformation of educational systems from promoting White dominance toward being culturally sustaining (Spanierman \& Smith, 2017). As DiAngelo observes, "our institutions were designed to reproduce racial inequity...the system only needs white people to be really nice... But niceness is not courageous... Interrupting racism takes courage and intentionality" (2018, p. 153).

Being "culturally sustaining...seeks...linguistic, literate, and cultural pluralism...for positive social transformation" (Paris \& Alim, 2017, p. 1). For example, with regard to language, a more culturally sustaining alternative to White Mainstream English hegemony is code-meshing, defined by Young (2018) as "blending vernacular language and dialects of English in speaking and writing" (p. 76). The goal of this approach "is to maximize (not minimize) rhetorical effectiveness. And the focus is on excellent communication rather than on how well one adheres to prescribed grammar rules in one dialect" (Young, 2018, p. 81). This supplants the notion that anything other than White Mainstream English is unacceptable and inferior.

A commitment to cultivate cultural competence can be demonstrated by confronting racism in persons and in policies, including interrupting and deconstructing microaggressions (Davis et al., 2016; Ratts et al., 2016). To adapt an aged adage, if we're not actively advocating for equity and justice where we work and live, we're permitting and/or promoting the present problems. Educators "must ask themselves if they will follow the mold or blaze a new trail... It essentially boils down to whether one chooses to do damage to the system or to the student" (Emdin, 2016, p. 206).

Regarding vehicles to assist in enhancing cultural responsiveness, there is a burgeoning base of empirical evidence supporting a host of interventions. For example, educators and supervisors may take a cue from curriculum that has shown success in increasing cultural competence in nursing faculty (Gibbs \& Culleiton, 2016). In addition, recent examinations have identified traits and attitudes associated with enhanced cultural competence, such as openness, cognitive racial attitudes, ethnoracial identity development, and social justice activism (e.g., Fietzer et al., 2018). Also, in a review of prejudice reduction efforts, Paluck and Green (2009) noted the track record of success garnered by interventions to promote positive intergroup contact and collaboration. 
Another hopeful note was sounded by Garriott et al. (2016), who found that brief educational- and/or entertainment-oriented efforts (e.g., documentaries) promote progress in cultural responsiveness in both cognitive and affective realms. Additional studies and interventions seeking ways to operationalize and enhance these qualities in students, supervisors, and faculty are enthusiastically encouraged.

\section{Conclusion}

Despite ongoing experiences of racism within graduate programs, 10 Black doctoral students spoke of reasons why they were able to trust White mentors in ways that were beneficial to them both personally and professionally. Participants described their White mentors as being critically conscious, forthrightly acknowledging their own privilege as well as the vulnerable position that these students were in within academia. Moreover, these Black participants chose to trust these White mentors because of the latter's track record for advocating for those without power. For some participants, experiencing interracial trust was deeply meaningful, having potential for future BlackWhite relationships.

Students of color bring extraordinary strengths and capital. Appreciation of these assets, along with recognition of the reciprocal nature of the mentoring relationship, would be a welcome development. It should be noted that participants found great value in these holistic mentoring relationships involving both professional and personal development and concerns, therefore reconsideration of what is often a culturally informed decision regarding strict professional boundaries appears justified. White mentors are called to be more proactive in seeking and humbly inhabiting these more inclusive relationships, along with initiating and sustaining dialogs about race, power, and marginalization in a space that is safe for these courageous conversations.

In academic settings, the value of formal mentoring (i.e., institutionally approved programs often featuring assignment of mentors) has been recognized; yet our participants' informal mentoring, featuring trusting relationships which develop organically over time, tends to be prefered and was also seen as more effective, especially by students of color. Faculty and supervisors can work with students to create a program climate that encourages the formation of these invaluable connections through open discussions about challenging topics in safe spaces, collaborative research and teaching opportunities, and fostering attitudes of openness, cultural empathy, and self-awareness, respect, and humility - modeled in interactions with students and with colleagues.

Additional inquiries into the enhancement of trust in interracial mentoring relationships are encouraged. Also, considering the value of effective mentoring and the current census of faculty in higher education, further examinations of factors which foster successful relationships between privileged status mentors and protégés with marginalized cultural identities could inform efforts to make this critical resource more accessible for all students (e.g., garnering the perspectives of trusted mentors who have been nominated by protégés with marginalized cultural identities). In addition, continued exploration of various means of enhancing the cultural competence of higher education faculty, supervisors, and students could provide guidance for needed growth in this vital area. On a broader scale, examining systemic policies and practices which perpetuate the marginalization of some students, staff, and faculty is a potentially potent line of inquiry 
to address the pervasive and pernicious inequities in education (e.g., admissions and hiring, evaluation standards, hegemonic linguistic expectations).

\section{References}

American Counseling Association (2014). Code of ethics. Retrieved from https://www.counseling.org/docs/default-source/ethics/2014-aca-code-ofethics.pdf?sfvrsn=fde89426_5

Baker, C. A., \& Moore III, J. L. (2015). Experiences of underrepresented doctoral students in counselor education. Journal for Multicultural Education, 9, 68-84. https://doi.org/10.1108/JME-11-2014-0036

Baker-Bell, A. (2020). Linguistic justice: Black language, literacy, identity, and pedagogy. Routledge.

Bell, T. J., \& Tracey, T. J. G. (2006). The relation of cultural mistrust and psychological health. Journal of Multicultural Counseling and Development, 34(1), 2-14. https://doi.org/10.1002/j.2161-1912.2006.tb00022.x

Boswell, J. N., Wilson, A. D., Stark, M. D., \& Onwuegbuzie, A. J. (2015). The role of mentoring relationships in counseling programs. International Journal of Mentoring and Coaching in Education, 4, 168-183. https://doi.org/10.1108/IJMCE-03-20150007

Brooks, M., \& Steen, S. (2010). "Brother where art thou?" African American male instructors' perceptions of the counselor education profession. Journal of Multicultural Counseling and Development, 38(3), 142-153. https://doi.org/10.1002/j.2161-1912.2010.tb00122.x

Brown, E. M. \& Grothaus, T. (2019). Experiences of cross-racial trust in mentoring relationships between Black doctoral counseling students and White counselor educators and supervisors. The Professional Counselor, 9, 211-225. https://doi.org/10.15241/emb.9.3.211

Butler, S. K., Evans, M. P., Brooks, M., Williams, C. R., \& Bailey, D. F. (2013). Mentoring African American men during their postsecondary and graduate school experiences: Implications for the counseling profession. Journal of Counseling \& Development, 91, 419-427. https://doi.org/10.1002/j.1556-6676.2013.00113.x

Carnegie Classification of Institutions of Higher Education (2015). About Carnegie classification. Retrieved from http://carnegieclassifications.iu.edu/

Cartwright, A. D., Avent-Harris, J. R., Munsey, R. B., \& Lloyd-Hazlett, J. (2018). Interview experiences and diversity concerns of counselor education faculty from underrepresented groups. Counselor Education \& Supervision, 57, 132-146. https://doi.org/10.1002/ceas.12098

Chadiha, L. A., Aranda, M. P., Biegel, D. E., \& Chang, C-W. (2014). The importance of mentoring faculty members of color in schools of social work. Journal of Teaching in Social Work, 34, 351-362. https://doi.org/10.1080/08841233.2014.937891 
Chan, A. W., Yeh, C. J., \& Krumboltz, J. D. (2015). Mentoring ethnic minority counseling and clinical psychology students: A multicultural, ecological, and relational model. Journal of Counseling Psychology, 62(4), 592-607. https://doi.org/ $10.1037 /$ cou0000079

Chun, J. U., Litzky, B. E., Sosik, J. J., Bechtold, D. C., \& Godshalk, V. M. (2010). Emotional intelligence and trust in formal mentoring programs. Group \& Organization Management, 35, 421-455. https://doi.org/10.1177/ 1059601110378293

Creswell, J. W. (2013). Research design: Qualitative, quantitative, and mixed methods approaches (4th ed.). SAGE.

Davis, D. E., DeBlaere, C., Brubaker, K., Owen, J., Jordan II, T. A., Hook, J. N., \& Van Tongeren, D. R. (2016). Microaggressions and perceptions of cultural humility in counseling. Journal of Counseling \& Development, 94, 483-493. https://doi.org/10.1002/jcad.12107

DiAngelo, R. (2018). White fragility: Why it's so hard for White people to talk about racism. Beacon Press. http://www.beacon.org/White-Fragility-P1631.aspx

Eller, L. S., Lev, E. L., \& Feurer, A. (2014). Key components of an effective mentoring relationship: A qualitative study. Nurse Education Today, 34(5), 815-820. https://doi.org/10.1016/j.nedt.2013.07.020

Emdin, C. (2016). For White folks who teach in the hood... and the rest of $y$ 'all too: Reality pedagogy and urban education. Beacon Press.

Fietzer, A. W., Mitchell, E., \& Ponterotto, J. G. (2018). Multicultural personality and multicultural counseling competency in counselor trainees. Counselor Education \& Supervision, 57, 82-97. https://doi.org/10.1002/ceas.12095

Gaddis, S. M. (2012). What's in a relationship? An examination of social capital, race and class in mentoring relationship. Social Forces, 90, 1237-1269. https://doi.org/ $10.1093 / \mathrm{sf} / \mathrm{sos} 003$

Garriott, P. O., Reiter, S., \& Brownfield, J. (2016). Testing the efficacy of brief multicultural education interventions in White college students. Journal of Diversity in Higher Education, 9, 158-169. https://doi.org/10.1037/a0039547

Gibbs, D. K., \& Culleiton, A. L. (2016). A project to increase educator cultural competence in mentoring at-risk nursing students. Teaching and Learning in Nursing, 11, 118125. https://doi.org/10.1016/j.teln.2016.01.003

Haizlip, B. N. (2012). Addressing the underrepresentation of African-Americans in counseling and psychology programs. College Student Journal, 46, 214-222.

Haskins, N., Whitfield-Williams, M., Shillingford, M. A., Singh, A., Moxley, R. \& Ofauni, C. (2013). The experiences of Black master's counseling students: A phenomenological inquiry. Counselor Education and Supervision, 52, 162-178. https://doi.org/10.1002/j.1556-6978.2013.00035.x

Hays, D. G., \& Singh, A. A. (2012). Qualitative inquiry in clinical and educational settings. The Guilford Press. 
Hays, D. G., Wood, C., Dahl, H., \& Kirk-Jenkins, A. (2016). Methodological rigor in Journal of Counseling \& Development qualitative research articles: A 15-year review. Journal of Counseling \& Development, 94, 172-183. https://doi.org/10.1002/jcad.12074

Henfield, M. S., Owens, D., \& Witherspoon, S. (2011). African American students in Counselor Education programs: Perceptions of their experiences. Counselor Education \& Supervision, 50, 226-242. https://doi.org/10.1002/j.15566978.2011.tb00121.x

Henfield, M. S., Woo, H. \& Washington, A. (2013). A phenomenological investigation of African American counselor education students' challenging experiences. Counselor Education \& Supervision, 52, 122-136. https://doi.org/10.1002/j.15566978.2013.00033.x

Holcomb-McCoy, C. \& Addison-Bradley, C. (2005). African American counselor educators' job satisfaction and perceptions of departmental racial climate.Counselor Education and Supervision, 45(1), 2-15. https://doi.org/10.1002/j.1556-6978.2005.tb00126.x

Hunt, B. (2011). Publishing qualitative research in counseling journals. Journal of Counseling \& Development, 89(3), 296-300. https://doi.org/10.1002/j.15566678.2011.tb00092.x

James, N. (2014). Using email interviews in qualitative educational research: Creating space to think and time to talk. International Journal of Qualitative Studies in Education, 29, 150-163. https://doi.org/10.1080/09518398.2015.1017848

Johnson-Bailey, J., \& Cervero, R. (2004). Mentoring in Black and White: The intricacies of cross-cultural mentoring. Mentoring and Tutoring, 12(1), 7-21. https://doi.org/10.1080/1361126042000183075

Keller, J., Mayo, R., Greifeneder, R., \& Pfattheicher, S. (2015). Regulatory focus and generalized trust: The impact of prevention-focused self-regulation on trusting others. Frontiers in Psychology, 6, 1-13. https://doi.org/10.3389/ fpsyg.2015.00254

Leck, J., \& Orser, B. (2013). Fostering trust in mentoring relationships: An exploratory study. Equality, Diversity, and Inclusion: An International Journal, 32, 410-425. https://doi.org/10.1108/EDI-01-2010-0007

Luedke, C. L. (2017). Person first, student second: Staff and Administrators of Color supporting Students of Color authentically in higher education. Journal of College Student Development, 58, 37-52. https://doi.org/10.1353 /csd.2017.0002

Malott, K. M., Paone, T. R., Schaefle, S., Cates, J., \& Haizlip, B. (2015). Expanding White racial identity theory: A qualitative investigation of Whites engaged in antiracist action. Journal of Counseling \& Development, 93, 333-343. https://doi.org/10.1002/jcad.12031 
McCoy, D. L., Winkle-Wagner, R., \& Luedke, C. (2015). Colorblind mentoring? Exploring White faculty mentoring of students of color. Journal of Diversity in Higher Education, 8, 225-242. https://doi.org/10.1037/a0038676

Moustakas, C. (1994). Phenomenological research methods. SAGE.

Owens, J., Tao, K. W., Drinane, J. M., Hook, J., Davis, D. E., \& Kune, N. F. (2016). Client perceptions of therapists' multicultural orientation: Cultural (missed) opportunities and cultural humility. Professional Psychology, 47, 30-37. https://doi.org/10.1037/pro0000046

Paluck, E. L., \& Green, D. P. (2009). Prejudice reduction: What works? A review and assessment of research and practice. Annual Review of Psychology, 60, 339-367. https://doi.org/10.1146/annurev.psych.60.110707.163607

Paris, D., \& Alim, H. S. (Eds.) (2017). Culturally sustaining pedagogies: Teaching and learning for justice in a changing world. Teachers College Press.

Protivnak, J. J., \& Foss, L. L. (2009). An exploration of themes that influence the counselor education doctoral student experience. Counselor Education \& Supervision, 48, 239-256. https://doi.org/10.1002/j.1556-6978.2009.tb00078.x

Rademaker, L. L., Duffy, J. O., Wetzler, E., \& Zaikina-Montgomery, H. (2016). Chair perceptions of trust between mentor and mentee in online doctoral dissertation mentoring. Online Learning, 20, 1-13. https://doi.org/10.24059/olj.v20i1.605

Ratts, M. J., Singh, A. A., Nassar-McMillan, S., Butler, S. K., \& McCullough, J. R. (2016). Multicultural and social justice counseling competencies: Guidelines for the counseling profession. Journal of Multicultural Counseling and Development, 44, 28-48. https://doi.org/10.1002/jmcd.12035

Rudolph, B. A., Castillo, C. P., Garcia, V. G., Martinez, A., \& Navarro, F. (2015). Hispanic graduate students' mentoring themes: Gender roles in a bicultural context. Journal of Hispanic Higher Education, 14, 191-206. https://doi.org/10.1177/ 1538192714551368

Smith, S. S. (2010). Race and trust. Annual Review of Sociology, 36, 453-475. https://doi.org/10.1146/annurev.soc.012809.102526

Spanierman, L. B., \& Smith, L. (2017). Roles and responsibilities of White allies: Implications for research, teaching, and practice. The Counseling Psychologist, 45, 606-617. https://doi.org/10.1177/0011000017717712

Terrell, F., \& Terrell, S. L. (1981). An inventory to measure cultural mistrust among Blacks. The Western Journal of Black Studies, 5(3), 180-184.

Townes, D. L., Chavez-Korell, S., \& Cunningham, N. J. (2009). Reexamining the relationships between racial identity, cultural mistrust, help-seeking attitudes, and preference for a Black counselor. Journal of Counseling Psychology, 56, 330-336. https://doi.org/10.1037/a0015449

Wertz, F. J. (2005). Phenomenological research methods for counseling psychology. Journal of Counseling Psychology, 52, 167-177. https://doi.org/10.1037/00220167.52.2.167 
Young, V. A., (2018). Code-meshing: The new way to do English. In V. A. Young, R. Barret, Y. Young-Rivera, \& K. B. Lovejoy, Other people's English: Code-meshing, code switching, and African American Literacy (pp. 76-83). Parlor Press.

\section{Author Contact}

Eric Brown, eric.brown@depaul.edu

DePaul University

College of Education, Counseling and Special Education Department

2247 N Halsted St, Chicago, IL 60614

Tim Grothaus, TGROTHAU@odu.edu

Old Dominion University

Department of Counseling and Human Services

1226 W 43rd St, Norfolk, VA 23508 